\title{
Contesting the Space in Indonesia: A Case From Al-Washliyah in North Sumatra
}

\author{
Faisal Riza
}

Faculty of Ushuluddin UIN North Sumatra-Indonesia. Willem Iskandar Pasar V Medan Estate Phone. 061-6615683.

6622925.Fax. 061-6615683, code 20371.

Email:fai_riza@yahoo.com

\begin{abstract}
In the atermath of the Reform movement in 1998, Indonesia has begun to face significant changes such as an increase in the degree of democratization through decentralization. Since 1998, there have been four general elections (1999, 2004, 2009) conducted in Indonesia. These elections include a presidential election by Legislative Assembly (1999), direct presidential elections (2004 and 2009), and elections of local government heads (Pilkada) in Indonesia's provinces, districts, and municipalities. Under these circumstances, Islamic civil society organizations are and have often been placed in the crossroad of the local politics. Al-

Washliyah, the biggest Islamic organization in North Sumatra, is not an exception. It has played a very profound role in local development in which political engagement has been unavoidable. There are many members of Al-Washliyah who works in political parties with various ideologies. Politicians often request AlWashliyah support especially in moments of Pilkada (regional election). This article focuses on the strategies of Al-Washliyah in development of democratization in North Sumatra, analyzing its moves, involvement, and the use of their organi-
\end{abstract}

zation in the electoral politics. It explains the transformation of AlWashliyah from cultural politics to practical politics in which AlWashliyah acts much like a political party.

Keyword: Al-Washliyah, decentralization, general election, political Islam

\footnotetext{
ABSTRAK

Setelah era reformasi, Indonesia menghadapi perubahan besar sosial politik di Indonesia, seperti meningkatnya demokrasi melalui desentralisasi pemerintahan. Sejak tahun 1998, terdapat empat kali periode pemilihan umum $(1999,2004,2009)$, yang ditandai dengan pemilihan presiden oleh anggora Dewan Perwakilan Rakyat (1999) dan tiga kali pemilihan presiden secara langsung (2004 dan 2009), serta ratusan pemilihan umum di tingkat provinsi dan kota/ kabupaten untuk menentukan kepala daerah. Pemilu-pemilu tersebut acap kali menempatkan organisasi masyrakat sipil Islam di persimpangan jalan politik lokal. Al-Washliyyah, sebuah organisasi Islam terbesar di Sumatra utara tidak terkecuali. Terdapat banyak anggota Al-Washliyah yang juga bergabung dalam partai-partai politik dengan latar belakang politik dan ideologi yang berbeda. Para politisi acapkali meminta dukungan Al-Washliyah pada saat pemilu umum di tingkat daerah. Untuk itu, tulisan ini mengkaji strategistrategi Al-Washliyah dalam mendorong demokratisasi di Sumatra Utara, dan menganalisis gerakan, keterlibatan dan penggunaan organisasi masyarakat sipil dalam pemilihan umum lokal. Tulisan ini menjelaskan transformasi Al-Washiliyah dari politik budaya kepada politik praktis dimana Al-Washliyah bertindak sebagaimana halnya partai politik. Hasil penelitian ini menunjukkan bahwa Al-Washliyah kerap dihadapkan pada sebuah dilema dalam memainkan peran gandanya. Di satu sisi, Al-Washliyah sebagai organisasi keagamaan harus mengutamakan dan menerapkan ajaran-ajaran moral dalam
} 
Islam, tetapi di sisi yang lain organisasi ini juga sering dikendalikan oleh permainan politik praktis dan kekuatan politik.

Kata Kunci: Al-Washliyah, desentralisasi, pemilihan umum, Islam politik

\section{INTRODUCTION}

Understanding Islam as a civilian power affecting social change in Indonesia should involve analysis of the history of the early twentieth century. That century was marked by the emergence of Islamic reformist movements, such as Muhammadiyah, NU, Syarekat Islam, Persis, Al-Irsyad, and AlWashliyah. An analysis of this history requires a rethinking of some basic assumptions about Islam and politics. The first step deals with politics in mind that the Muslims are not monolithic, as politics in a variety of civilizations, it plural. ${ }^{1}$ Referring to this, Steenbrink identifies four important factors that motivated its development. The first is determination to return to the principles of the Quran and the Hadith. The second is nationalism and motivation to resist the colonialism. The third is the need of strengthening the social, economic, cultural and politics. The fourth is the need for Islamic education reform in Indonesia. No ideas have a profound influence on political Islam in Indonesia refiguration such modern nationalism. ${ }^{2}$ In the first decade of the twentieth-century, Muslim leaders shift their sights away from the nightmare before generating pan-Islamic governments towards the goal of a multiethnic nation coinciding with the limit of the Dutch Indies. $^{3}$

Ahead of the fall of President Soeharto in 1998, the national debate about the future political order in Indonesia runs well. In the 1990 's, there are some issues that drew public attention. The dominant political discourse in Indonesia at that time include is a debate about what political system is supposed to run, the question of the legitimacy of the rule of President Soeharto and the relationship between Islam and the state, the military's role in politics, the potential for democratization, transition to the post-Suharto era, and the nature economic development. Here, Kato $^{4}$ and Douglas 5 said that Islam through NU, Muhammadiyah, and ICMI take a decisive role in establishing democracy. Efforts to reformulate of the relationship between Islam and politics both structurally and culturally. The fall of Soeharto in 1998 marks the beginning of the reformasi, a demand change in all aspects of civic life. Reformasi can be interpreted as two things, human mentality and political mechanisms called decentralization. In the case of a new human mentality civilized Indonesia, where human dignity including minorities and marginalized upheld in collective consciousness, associated with the first sight. The creation of an open and freely associated with the latter, the political mechanism. In a civilized society, ethics is very important, that is a good demand for self-esteeming and respecting for others.

Study on North Sumatra always use analytical sociology, politics, history and anthropology. Several studies on decentralization in North Sumatra have been made (Hadiz 2003; Aspinall 2011). While most studies on contemporary North Sumatra do not directly address to the Muslim community as a powerful force of change in society. Based on the thesis of Islam that has been and will continue to play a role in the democratization process in Indonesia, so in this article I focus on a pivotal moment in the course of contemporary Indonesia called 
reformasi and democratization in the region with the complexity of the local elections. I also focus on the analysis of how Al-Washliyah as the largest Muslim organization in North Sumatra plays a role in local politics, how the movements and strategies of al-Washliyah played in the process, and the precedent of what can be taken up and the Muslims to face and deal challenges in the future.

\section{AL-WASHLIYAH: TRADITIONAL AND MODERN}

Al-Jam'iyah Al-Washliyah or better known as Al-Washliyah is an organization of Muslim society in Indonesia, which has more than 2 million people. The organization was founded in Medan (when it entered East Sumatra) in 1930 by students who gathered in the "debating club" affiliated with Maktab Tapanuli Islamiyah (MIT) leader Haji Muhammad Yunus in Medan. They are Abdurrahman Shihab, Ismail Banda, M. Arsyad Talib Lubis, Yusuf Ahmad Lubis, and Adnan Nur Lubis. Major Al-Jam'iyah AlWashliyah triggered by al-Hajj Muhammad Yunus that mean associations bound. ${ }^{6}$ Choice of the name is closely related to socio-political situation at the time. This organization is a response to social and political complexities of the day, such as the growth of the modern movement, represented particularly by Muhammadiyah, as well as the repositioning of traditional authority when it held the mufti of the Malay Islamic kingdom, and also the organization of Al-Ittihadiyah as the organization in East Sumatra before AlWashliyah, resistance against Dutch colonialism and Christianization agenda that infiltrated inside.

Since its establishment, the organization has inherent characteristics, based on social relations, that is, competition with others. In addition to the Islamic modernist movement growing, there are also Christian missionaries increasingly sharpened its mission, especially in the land of Batak. So it is not surprising that al-Washliyah as a religious organization has a particular interest in politics to meet the existence and power boost development. Establishment of Al-Washliyah purpose is to promote, selfish, and adds propaganda of Islam. Determination is contained in the document bai'ah of Al-Washliyah. Therefore, it is understandable that the presence of AlWashliyah is fighting Islamic teachings to the public and fulfilled the teachings of Islam as a whole. B. J. Boland describes Al-Washliyah traditionally seen in the group of schools holding Imam Syafii determination. ${ }^{7}$ Accommodate the rituals like tepung tawar [Religious blessing ceremony by laying wreath, water, powder] in the Malay or upa-upa in the community of Tapanuli that common practices to expect the pleasure of God and protects them from disasters.

In contrast Karel A. Steenbrink found AlWashliyah is very complex, it is traditional and modern, although Al-Washliyah strictly hold schools of Imam Syafii but Al-Washliyah also accept western education model that is relevant to the times. ${ }^{8}$ In the early days of its development, they often held a parade on public streets and seemed to allow confound of men and women in the ranks of the convoy to celebrate the big day as the birth of the Islamic prophet Muhammad. One important factor regarding the characteristics of Al-Washliyah is its value system, which is rooted in religious orientation. Theologically, there are three principles in Al-Washliyah, admission to schools of Sunni Islamic jurisprudence, such as Hanafi, Maliki, Hanbali, 
and Syafii. ${ }^{9}$ Name of Imam latter more gain primacy in society of Al-Washliyah. The belief in the doctrine of monotheism or the oneness of God and acceptance of Sufism, the mystical orders and practices. In an effort to reach the ultimate goal the establishment of Al-Washliyah emphasized on three aspects, namely Islamic propaganda, education and social charity. ${ }^{10}$

In the first decade of its establishment, under the leadership of Abdurrahman Shihab and Arsyad Thalib Lubis, Al-

Washliyah successfully established Islam consignment, both in the Medan and outside. Consignment outside Medan as in Batak lands was founded in 1938, Islam consignment in Karo was founded in 1937, and others. Islamic missionaries greatly contributed significantly to the spread of Islam in particular in North Sumatra and in general in Indonesia. Achievement al-Washliyah in the field of Islamic propaganda can be confirmed from the third Congress of Indonesia Islamic Council (MIAI) in Solo 1941 who decided Al-Washliyah as Islam duty holder consignment in Indonesia. With this decision, it is obvious how to respect and trust MIAI conference that when it has had twenty-five members, submit to the continued development of Islam as Al-Washliyah as a largest Islamic organization at that time. Achievement of Al-Washliyah in Islamic propaganda also gets a compliment from a modernist cleric Haji Abdul Karim Amrullah (Buya Hamka) by stating:

"Is there an Islamic movement that can reach the record of the association such as al-Jami'ah al-Washliyah?. He was ten years old but has been able to spread Islam in the fertile valley of Porsea, so it has been found there no less than 20,000 new Muslims that because of its, jiggle made the cross, moving alone the church, with bells matched with the faint sound of the azan faintly up. Try to guess-estimated their own, how likely stuff 20 years later or 30 years." 11

In the same year, Al-Washliyah had an important educational institution in North Sumatra and manages tens of thousands of students and hundreds of schools and madrasah. ${ }^{12}$ In 1995 Al-Washliyah has 617 educational institutions spread across the districts in North Sumatra. The number consists of 156 units of various public schools and 462 units of madrasah. ${ }^{13}$ In addition, now Al-Washliyah already has 6 universities and higher education. ${ }^{14} \mathrm{Now}$ Al-Washliyah has nine orphanages to accommodate orphans, one health clinic, and the first Islamic banks and financial institutions.

\section{AL-WASHLIYAH AND POLITICS}

Convergence Al-Washliyah with politics can be seen since the establishment of this organization. As a modern organization AlWashliyah does not shy away from the various dimensions of life surrounding the Islamic community. The character of these organizations can be referenced in the thinking of at least Talcott Parsons said that organizations in the country are classified into four groups, among others: (1) economic-oriented company, (2) political orientation, (3) organization integrative care of usefulness in legal institutions and society as keepers patterns that contribute to maintain the pattern of culture, education, represented by the church and the school. ${ }^{15}$ However it can be argued that organizations often show multiple orientations simultaneously or sequentially with each other. A political organization, for example, may be associated with a company or business 
to help ensure the financial security of the organization. More plural again found religious organizations, educational and cultural traits have the political will to allow the organization to realize the goal of maintaining the cultural orientation in society. Affiliation with politics is important for several organizations for survival.

Affiliate religious organizations with powerful political organizations when it faced with a threat of religious organizations which can weaken the organization, either by harsh competition with other organizations as well as repression by the authorities. Here the position of Al-Washliyah with internal and external challenges cannot avoid double orientation, as well as political propaganda, propaganda as well as educational, economic, and cultural. Thus, even if Al-Washliyah always enthusiastic in social, educational and religious since its inception was equally concerned and even actively involved in politics. Although normatively Al-Washliyah does not regulate involvement in electoral politics, nor a political party and never set up his own political party, however, this organization has had a long history of involvement in politics through political parties.

Since the early years of its establishment, Al-Washliyah closely linked to political parties such as Masyumi in Sukarno era.

Abdurrahman Shihab when it was the chairman of the general Al-Washliyah simultaneously serving as commissioner of Masyumi for the region of North Sumatra and Aceh. Abdurrahman Shihab as a model for other activist of al-Washliyah then active in parliamentary politics both at the central and local levels. In eighth congress $1952 \mathrm{Al}$ Washliyah recommended Sharia Law (Law of marriage in Islam). It is intended that the
Muslims in the archipelago have certainty in their foster families based sharia. Besides its appearance and response insistence on elections. In this case, Congress insisted that the elections held as soon as possible and fight for Al-Washliyah to sit in parliament. In the period after World War II, it is understandable if people are Muslim Indonesia hopes to establish an Islamic State. AlWashliyah among social movements that encourage the establishment of an Islamic state and the basic laws of the State based on the Qur'an and Hadith. As described in the ruling clerics and preachers conferences across Indonesia which was then headed by Daud Beureueh and Abdurrahman Shihab.

"say to all Muslims in Indonesia are as follows: (a) each people State of Indonesia is Muslim, male and female, who have the right to vote according to the Indonesian election law was passed; shall exercise the right to vote by registering as voters and to vote at the time the vote was; shall select only candidates who have ideals and teachings of the implementation of Islamic law and the state. (B) the Muslim men and women who have legally, shall try and give all kinds of help and sacrifice to achieve the victory of Islam in the upcoming elections." 16

Furthermore, subjects also reported legislation (law) Islam.

"(a) The sovereignty and power. Sovereignty belongs to Allah entirely and authority to regulate the State of Indonesia conducted by the Indonesian people as God's message to the deliberations within the confines of Islamic law for the happiness of mankind and unseen. (b) The basic state. State based on Islam. (c) The legal basis for the State. Basic law of the State is the Quran and Hadith. (d) The form of the State. Country a republic is the head of state of 
a Muslim citizen. Head of State in charge of governance and responsibility to the people. (e) Human rights. State guarantees full human rights such as freedom and freedom of person, freedom of religion, freedom of thought and assembly and freedom of private property. Everyone (men and women are entitled to equal treatment in law and social justice, education, economics and politics. (d) The social economy. Economy regulated by the State Social and happiness for all people. ${ }^{17}$

Even as it turns over, the political achievements of Al-Washliyah never approached his achievements in the field of propaganda and education. Besides Masyumi banned by Sukarno in 1960 due to a conflict with his government, internal divisions in Islam, represented by the traditional group (NU) and Modern (Muhammadiyah) makes it difficult for Islamic groups to act as a powerful political force during the period of the Old Order. Although Masyumi formed thanks to the cooperation of several Islamic groups in Indonesia, the unity of the party was broken when a traditional NU withdrew from Masyumi in 1952. One reason is the dominance of the modernist group Masyumi and position of ministerial of religion in the Wilopo government. ${ }^{18}$ But B.J. Boland found that the conflict is a conflict of ideology. ${ }^{19}$ For take attention about discharging $\mathrm{NU}$ from Masyumi, Al-Washliyah sent wires to the NU Congress who was held in Palembang, also sent a similar cable to the central board Masyumi. Reported as follows; "Congratulations for the congress point NU nexus with Masyumi it can be would be completed together with members of the other, by discussion in the sixth congress of Masjumi the eight congress of Al-Washliyah in Porsea."
The letter was also sent to the Board Masyumi in Jakarta, as described as follows: "DPP Masjumi. We sent a wire to the NU congress follows during know about NU nexus with Masjumi can presumably be dealt with along with other privileged members by discussion sixth in the conference Masyumi TTK hope DPP Masjumi policy is to seek held wire Porsea VIII. "20

These divisions result in disappointment Muslims and Islamic parties. Obtaining vote Islamic parties in the 1955 election only confirmed the achievement of vote 43 per cent, 20 per cent Masyumi, and 18.4 per cent for NU and other Islamic parties. ${ }^{21}$ Then, Masyumi existence banned by the government, Al-Washliyah create more specialized movement toward social activism and away from practical politics, concentrates propaganda development and education and social charities. In 1986 the New Order government requires the use of ideology Pancasila as the sole foundation for any social organization. Responding to the fierce policy debate on the internal management of the inevitable. In the fourteenth Congress finally declared Al-Washliyah accept Pancasila [five principles] as the ideology of the organization. Al-Washliyah also has a large stake in the PPP (Unity Development Party), despite not trying to re-proposed Jakarta charter. Until now in the reform era political polarization by the presence of al-Washliyah cadres at various parties with various ideologies.

\section{DECENTRALIZATION AND LOCAL ELEC- TIONS SINCE 2005}

The fall of Soeharto in 1998 was the collapse of authoritarianism and opportunities shape the implementation of democracy in Indonesia. However, we must acknowledge 
that the New Order under Soeharto has reinforced a process of modernization and technological advancement. People's lifestyles have changed over the past three decades. Euphoria democracy illustrated by the emergence of various Islamic political parties along with many nationalist parties. Since the implementation of Law no. 22/1999 and Law no. 32/2004, the Indonesian political system recognized the so-called regional autonomy, also known as decentralization. Consequently, the central government believes that transferring some powers to local authorities to provide space and ensure the aspirations of the people in the area. ${ }^{22}$ Ideally, the concept of autonomy is a local democratized space to increase participation in the region, to pursue its interests without dictation from the center and can easily realize their welfare. B.C. Smith ${ }^{23}$ says that the emergence of attention to democratization in the region transition departing from a belief that democracy in the region will affect the democracy at the national level. This confirms that the increase in the quality of democracy in the region to improve the quality of democracy determinant influence on the national level. Quality course involves culture of democracy, education and the value of participation. Political goal of decentralization is to create a more fair and open between the Regional Centre within the framework of the Unitary State. Unity can be embedded in an atmosphere of political decentralization in governance by providing the opportunity and freedom to the Region to implement and administer the government.

Since 1999, regulations on local elections and parliaments constantly revised. Law No. $22 / 1999$ on regional administration said that the Governor, Regents and Mayors elected by parliament, in which each political party are represented in it. However, the selection of these no longer considered public because democratic process monopolized by political parties and people are often not aware of the electoral process. In order to respond to the wishes of the development emerging law on local elections, which are summarized in the law No.32/2004 on local government, this Act introduced direct elections by the people, instead of the regional elections through parliament. Since 2005 there are hundreds of direct elections of regional heads (elections) in Indonesia's provinces, districts and municipalities. Event of this election has been the attention of many scholars and researchers, especially about what is happening in regions of Indonesia who have undergone democratization.

However, the law still provides a great role for political parties, because the regulations require a candidate who will advance to the regional heads must have a minimum requirement of 15 percent representation in parliament. In other words, the candidate must ask for support from political parties with representation in parliament. The consequence of it all money and the political behavior of transactional politics as a trend among candidates for support from political parties and political parties get benefit from the tickets given to the candidates. To counter the monopoly of political parties in nominating candidates head of region, the year 2007 appears insistence procurement regulations allow candidates head of region via the personal or non-party (independent). Then in 2008 enacted regulation law No. 12/ 2008 on local government change regulations before No. 32/2004 to allow individual 
candidates following the local elections. But this rule only applies to elections at the provincial, district, and municipalities, does not apply in the presidential election. In this case, the nomination of the head of the region is not a single track for the candidates who want to get ahead in the elections.

The Ideal like this is not something that is easily realized, there are many problems of decentralization in regional Indonesia. ${ }^{24}$ North Sumatra has experience in implementing decentralized with various issues that surrounded. The research report the $\mathrm{Na}$ tional Development and Planning Agency (Bappenas) on Indonesian Democracy Index (IDI) in 2009 mentions that the index of democracy in North Sumatra is relatively low when compared to other provinces in Indonesia. ${ }^{25}$ All Aspects of political rights is the most problematic aspect in view of the status of democracy in North Sumatra. Wave direct election of regional heads in 2010 in different districts and the city in North Sumatra are considered to have a lot of problems. For example, the case of permanent voters list (DPT). Complicating the demographic data collection system used as the main source of election and consequently the people lost they right to vote. Good election is clean, honest, fair and free. These processes are characterized by the dominance of the role of money in influencing people's choice. Based on the records of the Constitutional Court (MK) almost every election 2010 in North Sumatra founded money politics case, indications of fraud on the court because of money politics held by the Constitutional Court. However, of all the elections in Mandailing Natal Constitutional Court decided to be repeated because it proved money politics massively. In addition, the organizers of election code violations. Case in Tebing Tinggi elections 2010, which passed the candidates lodged with a criminal case. Then, despite the Election Commission declared victorious of criminalist, the Court actually rejected the decision and recommend re-election.

Another aspect is the democratic institutions. The Democratic institution such as local government is considered by public that does not have an ideal role in the development of democracy. Therefore, autonomy is only to be enjoyed by local elites, become petty kings in their respective regions, relying on the tax levy burden society. Many regional head in some districts or cities involved corruption and became prisoners of the Commission, shows that autonomy has not gone as expected. Other highlights a political party in competence and championing the aspirations of the people. As the political media that is closest to the people instead of political parties are the most problematic, the lack of a clear organizational ideology, a bad cadre education system and established, and emphasize rent-seeking activities in an effort to utilize the cadres of political parties in parliament and the executive to profit from funds Budget. Then, the cadres of political parties in parliament did not have the qualifications and competence appropriate duties and functions. Since 1999 there has never been applicable local initiative from DPRD North Sumatra. Plus more of anarchism in the aspirations of the people has not shown a civilized manner. In 2009 urging people to fight for the expansion of Tapanuli province from North Sumatra and led to riots in parliament and led chairman of DPRD Abdul Aziz Lift attacked by the demonstrators. 
It should be noted that no matter how good the concept of decentralization will not mean anything for the social, economic and political regional communities when he was not seriously directed to enter rooted in the culture of the local bureaucracy and implemented properly. Moreover, the concept of decentralization is meaningless if not backed up by the creation of a democratic (democratic culture) is adequate for the community to be involved in the process and the dynamics of regional development.

The position of Al-Washliyah very strategic in this context as a civic organization that is used to build and strengthen civil society, but there are some problems in the way the organization operates. Ismed Batubara as intellectual of Al-Washliyah said that in the post-reformasi period is Al-Washliyah far behind Muhammadiyah and NU, at least some of the conditions that caused the problem. ${ }^{26}$ Firstly Management and organizational skills, the organizational structure of the center to branch officials in the villages did not work with the maximum in developing the organization's program. ${ }^{27}$ Such management is often viewed by the community as an organization that is run by private rather than the mission and interests, it affects the membership and recruitment and programs they run. It also affects the reputation of similar organizations in relation to society and government, and on the readiness of the community or local organizations to support their work. There are two parts to this problem. a) In connection with the management of the organization: who's running, who has, and who's responsible. b) Effective and efficiency programs. Is it efficient and effective, and whether or not having an impact? The result is often a committed organization and has great enthusiasm but could not actually been shown to achieve a lot in an attempt to realize their goal.

Second. Support and financial accountability, the most fundamental difficulty faced by Al-Washliyah is their ability to support themselves and become independent. Many assets of organizations such as educational institutions, orphanages, health clinics and land, are ruled by others. Weak organization's financial accountability is one cause of many AlWashliyah asset changes hands. Although there are efforts that their members will request financial accountability for their leader, but this is often not the case. Funding organizations rely on membership dues are not effective, the contribution of Muslim businessmen, volunteers who served legislative and local government aid through the government budget expenditures. This makes them dependent on the decisions of external actors, which in turn makes the implementation and long-term planning is uncertain. Third, advocacy skills. Since the beginning of the era of transition that followed the fall of Soeharto, Al-Washliyah has been extensively involved in advocacy on issues of Islam. This reflects their desire to break down the barriers built by New Order and call for the establishment of institutions of civil society and good governance.

Unlike NU who founded PKB (National Awakening Party) and Muhammadiyah founded PAN (National Mandate Party), AlWashliyah chose not affiliated with a political party, and does not set up his own political party in the post-Soeharto era. However, the position of Al-Washliyah very unique, because the members of these organizations actively involved in various political parties, especially 
in North Sumatra, be it PPP (Unity Development Party), Golkar, PDIP (Indonesia Democracy Party-struggle), Democrat Party, and other parties. They are often present at meetings held Al-Washliyah, even be good stewards of the core in it. Here, there are two conflicting assumptions. First, Al-Washliyah politically fragmented not monolithic and less cohesive as an organization and this organization because it only serves as a safe place to meet. Second, despite the political diversity in the Al-Washliyah very real, Al-Washliyah still offer shared container for the Muslims, seem paradoxical while maintaining political credibility. In practical terms, Al-Washliyah may serve as a large umbrella that protect the interests of its members are active in political parties and the mediator that gives a sense of unity among the Muslims if the political coalition necessary. In this case the role of AlWashliyah very large and prospective. In general, the political interests of political AlWashliyah is doing good and avoiding evil, to voice the interests of Muslims and uplift the welfare of the Muslims in the reform era. So in fact there are many Islamic political parties have the same goal and can help to achieve the interests of Al-Washliyah. With this configuration the efficiency and effectiveness of the organization depends on the relationship between elites in it. While it is understandable that the key issue to consolidate their coalitions are independent organizations.

Al-Washliyah has been and continues to participate in the development of a democratic society. This commitment is demonstrated in the involvement of its cadres in the various political parties, elections and local elections. Political parties participating in elections often enlist the support of these organizations, and in every moment the local elections, the candidates also came to ask support, it is they do to take the sympathy of most of the residents of Al-Washliyah. To arrange cadres participation in electoral politics is Al-Washliyah have given rules (conventions) for the provision of support to political parties and candidate head of regional.

In the 2004 election many cadres of AlWashliyah were active in various political parties participated as legislative candidates. In this context the passive attitude of the organization, does not endorse and favoring cadres involved in it. However, different attitudes shown by the organization's candidate Abdul Halim Harahap, ${ }^{28}$ who is a member of local councils (DPD RI). Halim candidacy as a member of DPD RI backed by several motives, among others: 1) Responding national political dynamics set out in the Act. 2) Awareness of the potential future AlWashliyah. 3) Council representing community groups in the regional are not tied to any political party. ${ }^{29} 4$ ) Enforcement of doing good and avoiding evil politics and simultaneously measure the bargaining power of political organization. 5) To contribute in the welfare of society through religious development. ${ }^{30}$ In the context of Halim nomination as a member of the board of DPD RI almost all organizations member involved to support, as well as socialization and campaigns. Organizations like the political machine moves to garner support from the community. Political work is the support of the central committee of Al-Washliyah in Jakarta through a letter of recommendation stating that the board of Al-Washliyah approve or recommend Abdul Halim Harahap, chairman of the Board of Directors of Region Al- 
Washliyah North Sumatra, as one of the prospective candidates for the DPD RI, representing the organization. ${ }^{31}$

TABLE1. VOTING MEMBER OF DPD RI IN ELECTION 2004

\section{NO NAME OF CANDIDATE} VOTE

1 Drs. H. Abdul Halim Harahap $810.232 \quad 15.38$

2 Ir. Nurdin Tampubolon $\quad 321.5706 .1$

3 Raja Inal Siregar $\quad 316.3586$

4 Drs. H. Yopie Sangkot Batubara 277.6495 .27

5 Parlindungan Purba, SH $\quad 245.021 \quad 4.65$

Resource: KPUD North Sumatra

This table describes the voice of five major of 47 candidates. The top five is eligible to get a seat DPD period 2004-2009. Halim striking than the other candidates, this incident claimed as evidence of the workings of the organization and the mass organization of AlWashliyah in providing support for their elite. It is also considered by the cadres as the initial force of the organization to be used as a political vehicle.

In the local elections of 2005, the cadres of Al-Washliyah not appeared full confidence in the election as regent or mayor. So the position of the organization only as a support group for the candidate who shows the same vision with the organization. Similarly, the election for governor of North Sumatra in 2008 al-Washliyah support to one candidate pair is Syamsul Arifin and Gatot Pujo Nugroho. In 2010 a second wave of elections in North Sumatra. About 23 districts in North Sumatra that implement direct elections, here there are a polarization of attitudes on political decisions based organizations in each region. In some areas such as Medan, Langkat, Binjai, Serdang Bedagai, Tebing Tinggi, Al-Washliyah only gives political support to one of the non-cadre candidates. However, in Tanjung Balai AlWashliyah nominate the chairman of the regional leaders M. Haryono and fully supported member of the organization. Haryono position here is a candidate for vice mayor, he accompanied Haji Buyung. When the couple enrolled to Election Commission, his supporters participated accompany waving the flag of Al-Washliyah. Although later, in the event the couple defeat by the Election Commission.

Step of Al-Washliyah increasingly bold in politics when elections Governor of North Sumatra in 2012. This time Al-Washliyah nominated Hasbullah Hadi as a candidate for Governor of North Sumatra. Hasbullah is a genuine cadre of Al-Washliyah, since as a student Hasbullah active in wing organization of Al-Washliyah until then he has served as chairman of the Al-Washliyah North Sumatra 2010-2015. Hasbullah political career was also shot when he was active in the Democrat party, in the 2004 election he managed to get a seat to parliament northern Sumatra and served as deputy head of parliament. Later, the 2009 elections Hasbullah also return the same as getting a ticket. The decision to nominate Hasbullah by the second working meeting area of Al-Washliyah North Sumatra which was held on March 31, 2012, in the letter stated decides carrying Hasbullah Hadi as a candidate for governor of North Sumatra in 2013 via the individual (nonparty). The results of the meeting were agreed by all leaders of the region to explain the turbulent political wriggling in the body of the largest Muslim organization in North Sumatra. Instructions issued to request the entire wing organizations and volunteers to participate and support this nomination fight. Interestingly, at the same time, 
Hasbullah as the Democrat party cadres is one of the few people designated as the nine team members through Decree No. 172/ INT/DPP.PD/IV/2012 dated 5 April 2012 related to the recruitment of prospective candidates the Governor and Deputy Governor of North Sumatra on Gubernatorial election 2013. Hasbullah paired with Aziddin as candidate for vice governor, a former caretaker at the Al-Washliyah Jakarta and former of House of Representative from the Democrat party.

As a candidate who supported by AlWashliyah organizations in North Sumatra is a new step in the history of Al-Washliyah own and North Sumatra. Because there are Islamic organizations recently nominated as a candidate in the election cadres Head area in the province, and there are also new independent candidates. Hasbullah pairs with Aziddin his senior, once the chairman of Central Board of Al-Washliyah in Jakarta and elite of Parliament from the Democrat Party. Here, Al-Washliyah really as a political party without a declaration. Ismet Batubara said that AlWashliyah do not want to be a supporter, as well as full support organizations in the victory Syamsul Arifin-Gatot Pujo Nugroho on Gubernatorial 2008 but more than that Al-Washliyah want to be a significant stage actor. ${ }^{32}$ However, Al-Washliyah step brings its chairman as a candidate for governor of North Sumatra, North Sumatra, was thwarted by the Commission because it did not meet the administrative requirements. ${ }^{33}$ In addressing this failure Ismet Batubara said that at least attempts to nominate $\mathrm{Al}$ Washliyah, Hasbullah want to reduce the dominance of political parties often do not pay attention to the quality of candidates, because the political parties to put forward transactional forms in determining who the candidate head regions. ${ }^{34}$ Thus, Al-Washliyah felt it was important to give criticism in the process of candidate selection in political parties, Al-Washliyah also did not want his political position undermined by the political parties, the political power of the organization for a long time only used as a medium of political transactions by a cadre of $\mathrm{Al}$ Washliyah were once active in a political party so that the organization does not get better benefits that help the organization and the community as a whole.

\section{CONCLUSION}

The most useful role for civil society organizations such as Al-Washliyah is to support and strengthen government institutions to foster civil society, and to always be aware that the institution of civil society does not stray from the purpose of their prodemocratic. Political parties are a means to channel the aspirations of the people and if they cannot demonstrate this functionality, civil society is losing. In Indonesia, the political parties at the moment so do not accommodate the aspirations of the people and contribute to society in an independent and critical. Often they understood oligarchy similar in structure and leadership, disconnected from the electorate, and cannot express the true aspirations of the supporters of the "grassroots". It is important to discuss what needs to be done to make political parties more concerned wishes the community organizations that contribute to civil society.

Here, Al-Washliyah needs to improve its capacity to look at issues of governance and development, and they should be able to analyze and think about it from the perspec- 
tive of the policy community. They should be able to express clearly their goal, to build a coalition of people and organizations with strong community and to understand better how to make their arguments to the public and places the decision was made.

The fact that Al-Washliyah are at the formative turmoil reflects factors and historical conditions faced by similar groups during the New Order. These problems also indicate that the associations and organizations need to adapt to the current situation and looking for effective work and can move on. One of the most progressive steps undertaken in the transition is the decentralization of government power and resources to the regions, civil society organizations need to understand how to work under this new structure as well as at the national level - that is, a level one in Jakarta to level Provincial and level two in the district or city, and also by the House of Representatives.

\section{ENDNOTES}

1 Robert. W. Hefner, Civil Islam; Muslim and Democratization in Indonesia, (The United Kingdom: Princeton University Press, 2000), p.7

2 Steenbrink, K. A. Pesantren Madrasah Sekolah Pendidikan Islam dalam Kurun Modern [Islamic Boarding School Islamic School and School Islamic Education within Modern Era], (Jakarta: LP3ES, 1986), p.37

3 R.W. Hefner, Civil Islam, p. 37

4 Hisanori Kato, Agama dan Peradaban; Islam dan Terciptanya Masyarakat Demokratis yang Beradab di Indonesia, (Jakarta: Dian Rakyat, 2002), p. 309

5 Douglas. F. Ramage, Politics in Indonesia, Democracy, Islam, and the Ideology of Tolerance, (USA: Roulete, 1995), p. xv

6 Pengurus Besar Al-Jam'iyatul Washliyah, Peringatan Seperempat abad Al-Washliyah, (Medan:Pengurus Besar Al-Washliyah, 1956), p. 38

7 Chalidjah Hasanuddin, Al-Jam'iyatul Washliyah: Api Dalam Sekam, (Bandung: Cipta Pustaka, 1998), p. 2

8 Karel A. Steenbrink, Pesantren..., p. 27

9 Lihat Anggaran Dasar/Anggaran Rumah Tangga AlWashliyah pasal 2

10 Ibid.,
11 Majalah Pedoman masyarakat, Th. VII. No. 83, 6 August 1941

12 Muhammad Junus, Sejarah Pendidikan Islam di Indonesia, (Jakarta: Bulan Bintang, 1957), p. 71

13 Majelis Pendidikan Al-Washliyah Sumatera Utara, Nama dan Alamat Sekolah/Madrasah Al-Jam'iyatul Washliyah Sumatera Utara, (Medan: PW Al-Washliyah Sumatera Utara, 1995)

14 Al-Rasyidin, Dinamika Historis Al-Jam'iyatul Washliyah di Sumatera Utara, (eds) Ja'far, Al-Jam'iyatul Washliyah; Potret Histori, Edukasi dan Filosofi, (Medan: Perdana Publishing, 2011), p. 58

15 Talcott Parsons, Structure and Process in Modern Societies, (New York: John Willey, 1960), p. 45-46

16 Nukman Sulaiman, Al-Washliyah 1/4 Abad, (Medan: PB Al-Washliyah, 1995), p. 186-189

17 Ibid.,

18 Mitsuo Nakamura, The Reformist Ideology of Muhammadiyah, (eds) J.J. Fox, Indonesia: The Making of A Culture, (Canberra: The Australian National University, 1980), p. 281

19 B.J. Boland. The Struggle of Islam in Modern Indonesia, (The Hague: Martinus Nijhoff, 1971), p. 194

20 Nukman Sulaiman, Al-Washliyah..., p. 165

21 Boland, The Struggle..., p. 52

22 Vedi R. Hadiz, Power and Politics in North Sumatra: the uncompleted reformasi, in E. aspinall and G. Fealy (eds), Local Power and Politics in Indonesia: Decentralisation and Democratisation, (Singapore: Institute of Southeast Asian Studies, 2003), pp. 12. See also Mark Turner and Owen Podger (eds), Decentralisation in Indonesia: Redesigning the State, (Canberra: Asia Pasific Press, 2003), p. 25

23 Smith, B.C. Local Government and the Transition to Democracy: a review article, Public Administration and Development, Vol. 18, issue 1, 1998, pp. 85-92.

24 Michael Buehler, Decentralisation and Local Democracy in Indonesia: the Marginalisation of the Public Sphere, (eds) Edward Aspinall and Marcus Mietzner, Problems of Democratisation in Indonesia Election, Institutions and Society, (Singapore: ISEAS, 2010), pp. 267-285

25 Bappenas RI, Dokumen Laporan Indeks Demokrasi Indonesia Tahun 2009

26 Ismed Batubara, Al-Jam'iyatul Washliyah Potret yang Berubah, (eds) Ja'far, Al-Jam'iyatul Washliyah; Potret Histori, Edukasi, dan Filosofi، (Medan: Perdana Publishing, 2011), p. 135

27 Ibid.,

28 Abdul Halim Harahap is a popular figure in the alWashliyah in North Sumatra. He was born May 11, 1958 in Medan. He spent his life in Medan, primary school to university. He Get his MA before he died in the tragedy of the plane crash in 2006 in Medan. Since Halim received his secondary school education in the 
al-Washliyah, and continued his studies at State Institute for Islamic Studies (IAIN) North Sumatra.

29 Dedi Iskandar Batubara, Keterlibatan Pengurus Aljam'iyatul Washliyah Pada Pemilihan Umum Legislatif Tahun 2004: Suatu Study Deskriptif Terpilihnya Drs. H. Abdul Halim Harahap Menjadi Anggota DPD RI, Thesis Magister Studi Pembangunan, USU, 2010, p. 68

30 Ibid., p. 70

31 Letter of Recommendation PB Al Washliyah No: EXT30/PB-AW/XIX/XII/2003 3 December 2003

32 Interview with author 6 November 2012

33 http://www.waspada.co.id/ index.php?option=com_content\&view=article\&id=263957:cagubjalur-independen-dinyatakan-gugur\&catid=41: pilkadasumut\&ltemid=64, accessed on 31 october 2012

34 Interview with author 6 November 2012

\section{BIBLIOGRAPHY}

Al-Rasyidin. 2011. Dinamika Historis Al-Jam'iyatul Washliyah di Sumatera Utara [Historical Dynamics AlJam'iyatul Washliyah in North Sumatra], (eds) Ja'far, AlJam'iyatul Washliyah; Potret Histori, Edukasi dan Filosofi [Al-]am'iyatul Washliyah; Images of History, Education and Philosophy], Medan: Perdana Publishing.

Aspinall. E, Dettman. S. and Warburton. E. 2009. When Religion Trumps Ethnicity: a Regional Election Case Study from Indonesia, South East Asia Research, Vol. 19, Issue 1, pp. 27-58 doi:10.5367/sear/2011.0034.

Bappenas RI. 2009. Document Reports Indonesian Democracy Index.

Batubara, Dedi. I. 2010. Keterlibatan Pengurus Al-Jam'iyatul Washliyah Pada Pemilihan Umum Legislatif Tahun 2004: Suatu Study Deskriptif Terpilihnya Drs. H. Abdul Halim Harahap Menjadi Anggota DPD RI [Involvement of Board Al-Jam'iyatul Washliyah In General Election 2004: A Descriptive Study election of Drs. H. Abdul Halim Harahap Being a Senator], Theses at Master Development Studies, University of North Sumatra.

Batubara, Ismet. 2011. Al-Jam'iyatul Washliyah Potret yang Berubah [Al-Jam'iyatul Washliyah Changing Images], (eds) Ja'far, Al-Jam'iyatul Washliyah; Potret Histori, Edukasi, dan Filosofi, [Al-]am'iyatul Washliyah; Images of History, Education and Philosophy] Medan: Perdana Publishing.

Boland, B. J. 1971. The Struggle of Islam in Modern Indonesia, The Hague: Martinus Nijhoff.

Buehler, M. 2010. Decentralization and Local Democracy in Indonesia: the Marginalisation of the Public Sphere, (eds) Edward Aspinall and Marcus Mietzner, Problems of Democratisation in Indonesia Election, Institutions and Society, Singapore: ISEAS, 2010, pp. 267-285

Hadiz, Vedi R. 2003. Power and Politics in North Sumatra: the uncompleted reformasi, Aspinall. E and Fealy. G. (eds), Local Power and Politics in Indonesia: Decentralisation and Democratisation, Institute of
Southeast Asian Studies, Singapore.

Hasanuddin, Chalidjah. 1998. Al-Jamiyatul Washliyah: Api Dalam Sekam [Al-Jamiyatul Washliyah: Fire In The Husk], Bandung: Cipta Pustaka.

Hefner, Robert. W. 2000. Civil Islam; Muslim and Democratization in Indonesia, The United Kingdom: Princeton University Press.

http://www.waspada.co.id/ index.php?option=com_content\&view=article\&id=263957:cagubjalur-independen-dinyatakan-gugur\&catid=41:pilkadasumut\&ltemid=64, accessed on 31 October 2012.

Junus, Muhammad. 1957. Sejarah Pendidikan Islam di Indonesia [History of Islamic Education in Indonesia], Jakarta: Bulan Bintang.

Kato, Hisanori. 2002. Agama dan Peradaban; Islam dan Terciptanya Masyarakat Demokratis yang Beradab di Indonesia, [Religion and Civilization; Islam and the creation of the Civilized Democratic Society in Indonesia], Jakarta: Dian Rakyat.

Majelis Pendidikan al Washliyah Sumatera Utara. 1995. Nama dan Alamat Sekolah/Madrasah Al-Jam'iyatul Washliyah Sumatera Utara [Assembly Education AlWashliyah North Sumatra, Name and Address of the School / Madrasah al Jam'iyatul Washliyah North Sumatra], Medan: Pimpinan Wilayah Al-Washliyah Sumatera Utara.

Nakamura, Mitsuo. 1980. The Reformist Ideology of Muhammadiyah, (eds) J.J. Fox, Indonesia: The Making of A Culture. Canberra: The Australian National University.

Parsons, Talcott. 1960. Structure and Process in Modern Societies, New York: John Willey.

Pedoman masyarakat, Th. VII. No. 83, 6 August 1941.

Pengurus Besar Aljam'iyatul Washliyah. 1956. Peringatan Seperempat abad Al-Washliyah [A quarter-century warning Al-Washliyah], Medan: PB Al-Washliyah.

Ramage, Douglas. F. 1995. Politics in Indonesia, Democracy, Islam, and the Ideology of Tolerance, USA: Routledge,

Smith, B.C. 1998. Local Government and the Transition to Democracy: a review article, Public Administration and Development, Vol. 18, issue 1, pp. 85-92.

Steenbrink, K. A. 1986. Pesantren Madrasah Sekolah Pendidikan Islam dalam Kurun Modern [Islamic Boarding School Islamic School and School Islamic Education within Modern Era], Jakarta: LP3ES.

Sulaiman, Nukman. 1995. Al-Washliyah 1/4 Abad [Quarter Century of Al-Wasliyah], Medan: PB Al Washliyah.

Turner, M. and Podger. 2003. O (eds) Decentralisation in Indonesia: Redesigning the State, Asia Pasific Press, Canberra 